\title{
The Research on Fiscal and Financial Policy to Coordinate Support Development of Low Carbon Economy- A Case Study of Heilongjiang Province of China
}

\author{
Rong Hongxia ${ }^{1,2}$ \\ ${ }^{1}$ School of Economics, Harbin University of Commerce, \\ Harbin, Heilongjiang 150028, China \\ ${ }^{2}$ Harbin Finance University \\ Harbin, Heilongjiang 150030, China \\ 64280034@qq.com
}

\begin{abstract}
Based on the commentary of literature, this paper discusses the problem of low-carbon economic development. On account of complete points of fiscal and financial policy to coordinate support low-carbon economic development, utilizing the model of coordination degree, construct and evaluate coordinate development degree index system of fiscal and financial policy in Heilongjiang Province of China. The results show that the two coordinated development still encounters a series of major challenges, it is difficult for the system evolution in the direction of coordinated development. To realize the harmonious development for promoting the development of low carbon economy possesses important practical significance. Proposed market gradually plays an important part in policy support. Simultaneously, accompanied increasing financial investment, to give full play to support and guide the direction of financial policy to low-carbon economy development, therefore, propose the idea that promote fiscal and financial policy to support low carbon economy coordinately.
\end{abstract}

Keywords: low carbon economy; fiscal; financial policy; coordinate development

\section{Background}

In the face of increasingly severe global warming trend and energy crisis, promoting the development of social economy in our country, we need to cope with the times challenge by changing the development mode. Undoubtedly, Low carbon economy is the best destination and the most important strategic initiatives, which are the best choice of optimizing economic development. Low carbon economy is a variety of fresh economic development mode, which can have a significant impact to the whole social development and promote low-carbon economic growth, so to maintain economic growth.

Developing low-carbon economy is a major strategic decision to the coordinated development of national economy, the strategy of the implementation is of the demand to build coordinate support system of reasonable fiscal and financial policy, to play a

Final Draft Date: 12, 20, 2015

Fund Project: Heilongjiang Province Philosophy and Social Science Fund Project (14C33); Applied Technology Research and Development Program in Heilongjiang (Project Number: GC13D306).

About the Author: Rong Hongxia (1979 - ), female, Harbin, Heilongjiang, a Ph. D. candidate in Harbin University of Commerce, majoring in applied economics; an associate professor of Harbin Finance University, engaged in international trade economics and fiscal theory. 
supportive role in safeguarding and promoting the development of low-carbon economy.

\section{Literature Review}

\subsection{Domestic and Overseas Research Status}

2.1.1. Research on the Financial Support of Low-Carbon Economy: (1) The implementation of the environmental tariff. Pigou (1920) first put forward the environmental pollution should be bear on the environmental pollution tax, namely the principle of "polluter pays". In the 70s last century, the organization for Economic Co-operation and Development (OECD) on the basis of the "polluter pays" principle have been studied and formulated a series of tax policies on ecological issues, after that, which lead to the development of environmental taxes in the world very quickly. Since the 80s last century, the countries attempt to implement environmental taxes increasing more and more. Nowadays, many countries have established their tax system suited to their own national conditions to increase the different types of environmental protection taxes. The government's help of each step of a low-carbon economic development, which contributes to achieve developing goals of a low carbon economy and sustainable economic and social development successfully.

(2) The Research on the fiscal and taxation policy system related to low-carbon economy. Yang Quanshe, Fu Qiang (2010) argued that along with the international community to pay attention to the extent of the problems of climate change increase daily, low-carbon economy has become an inevitable trend in the development of world economy, and therefore a great need in our country is to establish a fiscal and tax policy support system, which must be to support the development of low-carbon economy for the purpose. Jia Kang, Wang Min (2009) studied the fiscal and taxation policies related to promote clean development, and believed that China should actively use taxation, public investment, subsidies, government procurement, transfer payments, sewage charges and other series of green fiscal policy to promote clean development. Feng Jin (2010) considered effective solution to deal with the contradiction between climate change and economic development is low-carbon economy. China must establish a scientific and reasonable system of fiscal policy to increase financial investment expenditure, and use government subsidies, while the implementation of the relevant taxes and tax reform. Xu Bo (2010) suggested that to develop a low-carbon economy must not be separated from the strong support of fiscal and fiscal policy. Currently, the fiscal and taxation policies to support China's low-carbon economy development are not perfect which should need to be improved better.

(3) Tax policy is the aspect of the government to promote low-carbon economy. Tang Ming (2010) proposed the tax policy that the government to promote the development of low carbon economy was one of important regulation tools. The government should adopt energy tax, introduce carbon tax, try to implement environment tax, improve the tax preferential policies and other measures. And make tax reform and the development of low-carbon economic policy together, to set up tax policy support system to promote the development of low-carbon economy. Wu Chongsi (2010) argued that low carbon economy was the economic model based on "Three Lows": low emissions, low energy consumption, low pollution. The economic model had some limitations, needed a series of system and policy support. He explained that tax policy was an important tool. By optimizing the current tax system, and actively guide low-carbon production and consumption, Government could promote the construction of a resource-saving and environment-friendly society.

(4) The Research on fiscal and tax policy using the experience of international low carbon economy. Chen Xinping (2010) issued the research on fiscal and tax policies of some developed countries. He thought that developed countries had paid attention to the application of carbon taxes, adhered to the principle of a carbon tax revenue neutral country accounted for the majority, insisted on focusing on the leverage of government 
money and paid attention to cooperate with market mechanism. In promoting low-carbon economy development course, he presented some constructive suggestions, such as reforming the current tax system. Hu Shaoshan (2010) argued that China should be based on international typical regional and national experiences on the development of low-carbon economy for reference, researched and improved relevant tax policy. Through effective use of tax regulation function to achieve the goal of energy conservation and emissions reduction, Government could promote the development of low-carbon economy. On the basis of domestic and abroad low carbon economy development policy experience, Luo Hong (2011) put forward China's low carbon economy policy system framework should be composed of three types of policies: mandatory, incentive and voluntary policy.

\subsubsection{Research on the Financial Support for Low-Carbon Economic Development:}

(1) The aspects related to financial support for innovative low-carbon economy. Sonia Lab at T, Rodney R. White (2002) argued that the innovation of bank financial tools was a low carbon economy prompt action. While solving these environmental problems, they promoted the bank for a wide range of financial product innovation, and provided a more convenient and efficient financing channels to individuals and enterprises that banks would be active to make environmental protection performance. Feldmaneal (1997) Sehalteggeretal (2000) summed up the positive correlation between corporate performance in the field of investment environmental protection and its stakeholder performance, namely the financial institutions would carry out green finance to improve economic efficiency. Panayotou (2004) proposed the assertion that long-term economic growth curve and carbon emissions were shaped inverted "U" relationship. American Sustainable Asset Management (SM) (2006) analyzed domestic Annual sustainable Report of 58 industries, pointed out in order to enhance competitive advantage position, financial sector could choose environmental and social opportunities and risks can be as the breakthrough point of the strategic decision. Zhou Xiaochuan (2007) pointed out that the energy conservation and emissions reduction of financial innovation service work would be the project which China's financial institutions should focus on the developing, strengthen corporate social responsibility consciousness and risk control ability of the financial system in the environmental protection and the development of low carbon economy, and should be established complete set of excellent information disclosure and sharing mechanism.

(2) The Aspects concerned to the carbon financial transactions. World Bank Development Report $(2006,2007)$ The Development Report issued by World Bank analyzed the role of carbon financial due to the formation of low-carbon economic development and emphasized the development of carbon financial transactions in Chicago Climate Exchange (CCX). London International Financial Services Authority (exploration, 2007) studied the EU carbon trading financial market. The EU carbon emissions trading system tended to be perfected, which should be regarded as a successful model to promote other countries and regions in the world.

(3) The aspects related to the green finance. Martin Nell \& Andreas Richter (2000) joint researched the management innovation of green finance and insurance industry and pointed out that the insurance industry needed innovate to climate change, environmental protection and corporate social responsibility etc. Paul Thompson. And Christopher J. Cowton (2004) believed that banks implemented green credit while including in corporate loans, weakened at the company's profitability factor, and instead, focuses on environmental protection other than corporate profits, and the implements preferential interest rates. Guo Peiyuan (2005) proposed the development strategy of domestic financial industry in accordance with the specification, which provided a very important reference value for China to develop green finance. Deng Xingwen (2007) pointed out that financial institutions should actively respond to the economic support of the national 
environmental policy and industrial policy, give companies or research institutions which research low carbon environmental protection technology and the development of new energy technology preferential policies of low interest loans. Gong Jian (2008) pointed out that the banking industry to implement green credit can not only support the enterprises to develop low carbon economy, but also help to solve environmental problems while having very important significance for their own sustainable development of the financial sector. Zhang Yanjiao (2008) argued that banks as the main green financial practitioners should be aware of green finance plays an important role in the social and economic development, and required that the green credit should be as a long-term development strategy of banking financial institutions. Wang Ran (2009) analyzed the reasons of obstructing the development of green finance in China, which was lack of a clear green financial guidance catalogue and environmental risk rating criteria.

\subsection{The Research on Domestic and International Development Trend}

The majority of the scholars in Chinese and foreign countries have raised the taxation and financial policies to support low-carbon economic development strategy, but few scholars from the coordination of fiscal and financial policy thought forward direction of low-carbon economy development in Heilongjiang Province of China. The research was lack of both fiscal and financial policies to promote the coordinated development of low-carbon economy. The development of low-carbon economy and the support of taxation financial policy is a more complex system which contains multiple influence factors, We need to grasp the overall research, but the current study is more reflected in the factors that support the low-carbon economy and financial policy for lack of attention to other factors; There is lack of studying on a policy framework for the operability and systematic analysis of fiscal and taxation coordinated development to promote the development of low-carbon economy. And there is also lack of deep analyzing interactive coordinated development problems and the reasons from the point of view of the coordinated development of the fiscal and financial policy to promote low carbon economic development is insufficient too. In view of the above reasons, this article selects the fiscal policy and financial policy index, which can be more fully reflect the coordinated development of both fiscal and financial policies to promote low-carbon economy empirically. From the perspective of constructing the model of coordination degree, in order to analyze the situation of developing the fiscal and financial policies coordinately to promote the low-carbon economic development, （加 入 we should) discuss policy suggestions on both policies to promote the low-carbon economy development under the condition of coordinate development.

\section{Fiscal and Financial Policy Coordinate Support Mechanisms of Developing Low-Carbon Economy}

\subsection{Theoretical Foundation}

Low carbon economy is based on the concept of sustainable development, technology innovation, industrial transformation, new energy development, and other forms as the goal which tries to reduce the high carbon energy consumption and greenhouse gas emissions and achieve economic development and ecological environment protection, which is a win-win economic development form.

Coordination is a positive correlation relationship between two or among more systems and system elements, which is a system or system internal elements to coordinate properly, harmonize consistently to a virtuous circle relationship network.

\subsection{The Fiscal and Financial Policy Framework to Coordinate Support the Development of Low-Carbon Economy}


The Coordination of fiscal policies and financial policies is to coordinate the relationship between government and the market, which is crucial for the development of low-carbon economy, and it needs to clarify their responsibilities. The government and the market should be distinct; meanwhile, the scope of their functions and responsibilities respectively should be according to the objective laws of market economy. the government's responsibilities is reflected in the use of financial subsidies, tax, transfer payments and so on, to support and restrain low-carbon economy development; The financial sector should intensify credit support to the development of low carbon economy; and establish the corresponding low carbon credit trading platform, promote low carbon trading, etc. Composition of forces from the fiscal and financial policy coordination can enlarge the effect of policy so as to promote the development of low carbon economy [1].

\section{Empirical Research}

Proceeding from the system theory, his paper does the research on Heilongjiang Province of China as an example. Heilongjiang Province is one of China's resource-based provinces, with a large number of mineral resources, such as coal and petroleum. For a long time, the development and utilization of resources has brought the huge impact to the environment, so low carbon economy development is imminent. This paper builds and evaluates index system of fiscal and financial policy coordination development degree in Heilongjiang Province of China nearly for a decade using the coordination degree model, comprehensive research and identifies the fiscal and financial policy coordination development situation, which has important practical significance to realize the harmonious development of both for promoting low-carbon economic development.

\subsection{Index System, Model Building and Data Sources}

4.1.1. Construction of Evaluation Index System: This paper follows the established index system of (among) the scientific, operational, dynamic and systematic principles combined with low carbon economic development in Heilongjiang Province of China, build the coordination development evaluation index system of fiscal policy and financial policy (table $1)$.

4.1.2. Standardization of Data Processing and the Determination of Index Weight:To unify the index and narrow dimension of magnitude difference between indicators, it adopts the method of standardization of poor to normalize the raw data. The formula is as follows:

$X C_{i j}=\left(x_{i j}-\min \left(X_{j}\right)\right) /\left(\max \left(X_{j}\right)-\min \left(X_{j}\right)\right)$

$X C_{i j}=\left(\max \left(X_{j}\right)-X_{i j}\right) /\left(\max \left(X_{j}\right)-\min \left(X_{j}\right)\right)$

In Formula (1) and (2), $\mathrm{X}_{\mathrm{ij}}$ represents the value of $\mathrm{j}$ index of $\mathrm{i}$ year, $\mathrm{XC}_{\mathrm{ij}}$ as the index value after normalization, $\max \left(X_{j}\right)$ is the maximum index item $\mathrm{j}, \min \left(X_{\mathrm{j}}\right)$ is the minimum value item $\mathrm{j}$ index. When the index larger is better for the system development, the author processes calculation formula (1) using positive index; When index smaller is better for the system development, the author processes calculation formula (1) using negative index (Table 1).

Table 1. The Determination to the Weights of Each Criteria Layer, Index Layer and Index Factor used Analytic Hierarchy Process (AHP))

\begin{tabular}{c|c|c|c}
\hline $\begin{array}{c}\text { Target } \\
\text { Level }\end{array}$ & Constrained Level & Index Level & Weight \\
\hline
\end{tabular}




\begin{tabular}{|c|c|c|c|}
\hline \multirow{5}{*}{$\begin{array}{c}\text { Fiscal } \\
\text { Policy } \\
\mid \\
\text { Financial } \\
\text { Policy } \\
\text { System }\end{array}$} & \multirow{3}{*}{$\begin{array}{c}\text { Fiscal Policy System } \mathrm{f}(\mathrm{x}) \\
0.5\end{array}$} & Financial Subsidy & 0.25 \\
\hline & & Budget Allocations & 0.10 \\
\hline & & Tax Preference & 0.15 \\
\hline & \multirow{2}{*}{$\begin{array}{l}\text { Financial Policy System g (y) } \\
0.5\end{array}$} & Green Loans & 0.61 \\
\hline & & Carbon Trading & 0.39 \\
\hline
\end{tabular}

4.1.3. Data Sources: According to the index system, processing and computing the original data is obtained from 2004 to 2013, 10 years in Heilongjiang Province, Statistical Yearbook of China.

\subsection{Related to Calculation for the Fiscal and Taxation Policy and the Coordination Development under Financial Policy}

\subsubsection{The Verall Level Index Calculation of Fiscal Policy and Financial Policy}

Coordination Development: According to the standardized values and weights of each index, the author calculates the fiscal policy development and comprehensive level of financial policy by weighted summation. Let $X_{i}(i=1,2,, m)$ for the fiscal policy development indicators, $Y_{j}(j=1,2,, n)$ for the financial policy indicators, corresponding weights are $\mathrm{W}_{\mathrm{i}}$ and $\mathrm{W}_{\mathrm{j}}$ respectively.

$$
\mathrm{f}(\mathrm{x})=\sum_{i=1}^{m} w_{i} x_{i} \text { and } \mathrm{g}(\mathrm{y})=\sum_{j=1}^{n} w_{j} y_{j} \text { represent the fiscal policy development and the }
$$
comprehensive situation of financial policy respectively.

4.2.2. Coordination Degree Calculation of Fiscal Policy and Financial Policy: Coordination degree calculation model is more, each has advantages and disadvantages. Here uses coordination degree model to analyze which is put forward by Liao Chongbin as follows:

$$
\mathrm{C}=\left\{\frac{f(x) \times g(y)}{\left[\frac{f(x)+g(y)}{2}\right]^{2}}\right\}^{k}
$$

$C$ is coordination degree which range is $[0,1]$, maximum (1) means that the optimum coordination state; On the other hand, while the coordination degree $C$ value is getting smaller, the more uncoordinated. Due to the coordination degree in some cases, it is difficult to reflect the overall function of the financial policy and fiscal policy or the benefits of the both policies (or level of development), and it is not conducive to inter-regional comparisons (in the same coordinate degree cases, comprehensive development level of fiscal policy and financial policy may vary greatly. Therefore, it measures the level of taxation policy and financial policy coordination level of development called the coordinated development of quantitative indicators, calculated as follows: Therefore, the quantitative index to measure coordination development level of the fiscal policy and financial policy is called the coordinated development degree, calculation formula is: 
$T=A f(x)+B g(y)$

$D=C \times T$

Equation (3), (4), (5), $\mathrm{C}$ is the coordination degree, $k$ is the adjustment coefficient, and $k \geq 2$ (due to the calculation is the degree of coordination between the two systems, $k$ take 2), $T$ for comprehensive evaluation index of the fiscal policy and financial development level, $A$ and $B$ is undetermined weight. Due to the development of fiscal policies is as important as the use of financial policies, so take $A=B=0.5, D$ for the coordinated development degree, the range of values $[0,1]$. In accordance with the method above, calculate coordination development degree of fiscal policy and financial policy in Heilongjiang Province of China from 2004 to 2013 (Table 2).

Table 2. Classification of Fiscal Policy and Financial Policy Coordination Development Degree in Heilongjiang Province of China from 2004 to 2013]

\begin{tabular}{c|c|c|c|c|c|c|c|c|c|c}
\hline & \multicolumn{3}{|c|}{ Fiscal Policy Index } & \multicolumn{3}{c|}{ Financial Policy Index } & \multicolumn{3}{c}{$\begin{array}{c}\text { Coordination } \\
\text { Development Degree }\end{array}$} \\
\hline years & $\begin{array}{c}\text { Financial } \\
\text { Subsidy }\end{array}$ & $\begin{array}{c}\text { Budgetary } \\
\text { Allocations }\end{array}$ & $\begin{array}{c}\text { Tax } \\
\text { Deduction }\end{array}$ & $\mathrm{f}(\mathrm{x})$ & $\begin{array}{c}\text { Green } \\
\text { Loans }\end{array}$ & $\begin{array}{c}\text { Carbon } \\
\text { Trading }\end{array}$ & $\mathrm{g}(\mathrm{y})$ & $\mathrm{C}$ & $\mathrm{T}$ & $\mathrm{D}$ \\
\hline 2004 & 0.065 & 0.115 & 0.070 & 0.038 & 0.018 & 0.043 & 0.028 & 0.954 & 0.03 & 0.03 \\
\hline 2004 & 0.254 & 0.428 & 0.313 & 0.153 & 0.112 & 0.058 & 0.091 & 0.874 & 0.12 & 0.11 \\
\hline 2005 & 0.322 & 0.465 & 0.378 & 0.184 & 0.156 & 0.102 & 0.135 & 0.956 & 0.16 & 0.15 \\
\hline 2006 & 0.427 & 0.578 & 0.468 & 0.235 & 0.175 & 0.201 & 0.185 & 0.973 & 0.21 & 0.20 \\
\hline 2007 & 0.487 & 0.674 & 0.521 & 0.267 & 0.198 & 0.320 & 0.246 & 0.997 & 0.26 & 0.26 \\
\hline 2008 & 0.566 & 0.698 & 0.545 & 0.293 & 0.245 & 0.456 & 0.328 & 1.002 & 0.31 & 0.31 \\
\hline 2009 & 0.612 & 0.714 & 0.674 & 0.326 & 0.289 & 0.589 & 0.406 & 0.970 & 0.37 & 0.36 \\
\hline 2010 & 0.688 & 0.724 & 0.693 & 0.348 & 0.345 & 0.596 & 0.443 & 0.994 & 0.39 & 0.39 \\
\hline 2011 & 0.722 & 0.789 & 0.799 & 0.379 & 0.398 & 0.668 & 0.503 & 0.965 & 0.44 & 0.43 \\
\hline 2013 & 0.799 & 0.798 & 0.955 & 0.423 & 0.412 & 0.727 & 0.535 & 0.987 & 0.48 & 0.47 \\
\hline
\end{tabular}

In order to reveal the extent of fiscal policy and financial policy coordination development, so need to classify coordinated development degree. In this paper, still use type division method of the coordinated development degree, which is put forward by Liao Chongbin [2], three levels of 30 types (Table 3)

Table 3. Classification System and Criteria of Taxation Policy and Financial Policy Coordinate Development

\begin{tabular}{c|c|c|c}
\hline $\begin{array}{c}\text { Coordination } \\
\text { Degree }\end{array}$ & Types & $\begin{array}{c}\text { Relationship between } f \\
(x) \text { and } g(y)\end{array}$ & $\begin{array}{c}\text { Types of Coordinated } \\
\text { development }\end{array}$ \\
\hline \multirow{2}{*}{$0.90 \sim 1.00$} & $\begin{array}{c}\text { Coordination } \\
\text { Development } \\
\text { Class }\end{array}$ & $f(x)<g(y)$ & $\begin{array}{c}\text { Good coordination } \\
\text { development class and } \\
\text { hysteretic fiscal and } \\
\text { taxation policy }\end{array}$ \\
\cline { 3 - 4 } & & $f(x)=g(y)$ & $\begin{array}{c}\text { Good coordination } \\
\text { development class; } \\
\text { financial policy and fiscal } \\
\text { policy synchronous }\end{array}$ \\
\cline { 3 - 4 } $0.80 \sim 0.89$ & $\begin{array}{c}\text { Coordinated } \\
\text { Development } \\
\text { class }\end{array}$ & $f(x)>g(y)$ & $\begin{array}{c}\text { Good coordination } \\
\text { development class and } \\
\text { hysteretic financial policy }\end{array}$ \\
\cline { 3 - 4 } & & $f(x)=g(y)$ & $\begin{array}{c}\text { Well coordination } \\
\text { development class; } \\
\text { hysteretic fiscal and } \\
\text { taxation policy }\end{array}$ \\
\hline & & & Well coordination \\
\hline
\end{tabular}




\begin{tabular}{|c|c|c|c|}
\hline & & & $\begin{array}{c}\text { development class; } \\
\text { financial policy and fiscal } \\
\text { policy synchronous }\end{array}$ \\
\hline & & $f(x)>g(y)$ & $\begin{array}{c}\text { Well coordination } \\
\text { development class and } \\
\text { hysteretic financial policy }\end{array}$ \\
\hline \multirow{3}{*}{$0.70 \sim 0.79$} & \multirow{3}{*}{$\begin{array}{l}\text { Intermediate } \\
\text { Coordinated } \\
\text { Development } \\
\quad \text { class }\end{array}$} & $f(x)<g(y)$ & $\begin{array}{l}\text { Intermediate coordination } \\
\text { development class and } \\
\text { hysteretic fiscal and } \\
\text { taxation policy }\end{array}$ \\
\hline & & $f(x)=g(y)$ & $\begin{array}{l}\text { Intermediate coordination } \\
\text { development class; } \\
\text { financial policy and fiscal } \\
\text { policy synchronous } \\
\end{array}$ \\
\hline & & $f(x)>g(y)$ & $\begin{array}{l}\text { Intermediate coordination } \\
\text { development class and } \\
\text { hysteretic financial policy }\end{array}$ \\
\hline \multirow{3}{*}{$0.60 \sim 0.69$} & \multirow{3}{*}{$\begin{array}{c}\text { Primary } \\
\text { Coordination }\end{array}$} & $f(x)<g(y)$ & $\begin{array}{l}\text { Primary coordination } \\
\text { development class and } \\
\text { hysteretic fiscal and } \\
\text { taxation policy }\end{array}$ \\
\hline & & $f(x)=g(y)$ & $\begin{array}{c}\text { Primary coordination } \\
\text { development class; } \\
\text { financial policy and fiscal } \\
\text { policy synchronous }\end{array}$ \\
\hline & & $f(x)>g(y)$ & $\begin{array}{c}\text { Primary coordination } \\
\text { development class and } \\
\text { hysteretic financial policy }\end{array}$ \\
\hline \multirow{3}{*}{$0.50 \sim 0.59$} & \multirow{3}{*}{$\begin{array}{l}\text { Reluctant } \\
\text { Coordinated } \\
\text { Development } \\
\text { class }\end{array}$} & $f(x)<g(y)$ & $\begin{array}{l}\text { Reluctant coordination } \\
\text { development class and } \\
\text { hysteretic fiscal and } \\
\text { taxation policy }\end{array}$ \\
\hline & & $f(x)=g(y)$ & $\begin{array}{l}\text { Reluctant coordination } \\
\text { development class; } \\
\text { financial policy and fiscal } \\
\text { policy synchronous }\end{array}$ \\
\hline & & $f(x)>g(y)$ & $\begin{array}{l}\text { Reluctant coordination } \\
\text { development class and } \\
\text { hysteretic financial policy }\end{array}$ \\
\hline \multirow{3}{*}{$0.40 \sim 0.49$} & \multirow{3}{*}{$\begin{array}{l}\text { On the brink } \\
\text { of Recession } \\
\text { Class }\end{array}$} & $f(x)<g(y)$ & $\begin{array}{l}\text { On the brink of recession, } \\
\text { the fiscal policy of profit } \\
\text { and loss class }\end{array}$ \\
\hline & & $f(x)=g(y)$ & $\begin{array}{l}\text { On the brink of recession, } \\
\text { the fiscal policy and } \\
\text { financial policy of common } \\
\text { benefit class }\end{array}$ \\
\hline & & $f(x)>g(y)$ & $\begin{array}{l}\text { On the brink of recession, } \\
\text { the financial policy of profit } \\
\text { and loss class }\end{array}$ \\
\hline $0.30 \sim 0.39$ & $\begin{array}{l}\text { Disorder of } \\
\text { Mild } \\
\text { Recession }\end{array}$ & $f(x)<g(y)$ & $\begin{array}{c}\text { Disorder of Mild } \\
\text { Recession, the fiscal policy } \\
\text { of profit and loss class }\end{array}$ \\
\hline
\end{tabular}




\begin{tabular}{|c|c|c|c|}
\hline & Class & $f(x)=g(y)$ & $\begin{array}{l}\text { Disorder of Mild } \\
\text { Recession, the fiscal policy } \\
\text { and financial policy of } \\
\text { common benefit class }\end{array}$ \\
\hline & & $f(x)>g(y)$ & $\begin{array}{c}\text { Disorder of Mild } \\
\text { Recession, the financial } \\
\text { policy of profit and loss } \\
\text { class } \\
\end{array}$ \\
\hline \multirow{3}{*}{$0.20 \sim 0.29$} & \multirow{3}{*}{$\begin{array}{l}\text { Moderate } \\
\text { Recession } \\
\text { Class }\end{array}$} & $f(x)<g(y)$ & $\begin{array}{l}\text { Moderate Recession, the } \\
\text { fiscal policy of profit and } \\
\text { loss class }\end{array}$ \\
\hline & & $f(x)=g(y)$ & $\begin{array}{l}\text { Moderate Recession, the } \\
\text { fiscal policy and financial } \\
\text { policy of common benefit } \\
\text { class }\end{array}$ \\
\hline & & $f(x)>g(y)$ & $\begin{array}{l}\text { Moderate Recession, the } \\
\text { financial policy of profit } \\
\text { and loss class }\end{array}$ \\
\hline \multirow{3}{*}{$0.10 \sim 0.19$} & \multirow{3}{*}{$\begin{array}{l}\text { Serious } \\
\text { Imbalance } \\
\text { Recession } \\
\text { Class }\end{array}$} & $f(x)<g(y)$ & $\begin{array}{l}\text { Serious Imbalance } \\
\text { Recession, the fiscal policy } \\
\text { of profit and loss class }\end{array}$ \\
\hline & & $f(x)=g(y)$ & $\begin{array}{c}\text { Serious Imbalance } \\
\text { Recession, the fiscal policy } \\
\text { and financial policy of } \\
\text { common benefit class }\end{array}$ \\
\hline & & $f(x)>g(y)$ & $\begin{array}{c}\text { Serious Imbalance } \\
\text { Recession, the financial } \\
\text { policy of profit and loss } \\
\text { class }\end{array}$ \\
\hline \multirow{3}{*}{$0 \sim 0.09$} & \multirow{3}{*}{$\begin{array}{l}\text { Extreme } \\
\text { Imbalance } \\
\text { Recession } \\
\text { Class }\end{array}$} & $f(x)<g(y)$ & $\begin{array}{l}\text { Extreme Imbalance } \\
\text { Recession, the fiscal policy } \\
\text { of profit and loss class }\end{array}$ \\
\hline & & $f(x)=g(y)$ & $\begin{array}{l}\text { Extreme Imbalance } \\
\text { Recession, the fiscal policy } \\
\text { and financial policy of } \\
\text { common benefit class }\end{array}$ \\
\hline & & $f(x)>g(y)$ & $\begin{array}{l}\text { Extreme Imbalance } \\
\text { Recession, the financial } \\
\text { policy of profit and loss } \\
\text { class }\end{array}$ \\
\hline
\end{tabular}

\subsection{Consequence Analysis, Forecast and Conclusion}

4.3.1. Analysis of Evaluation Result According to Table 2, and Table 3, the analysis shows that from 2004 to 2013, the overall coordinated development degree of fiscal and financial policy in Heilongjiang Province of China was slowly rising, 2004 2005 belonged to serious imbalance recession class, 2006-2007 belonged to moderate recession class, 2008-2010 belonged to disorder of mild recession class, development from 2011 to 2013 was maladjusted to the brink of recession class. From the third level in table 3, 2004 to 2007 was of financial policy of profit and loss class and hysteretic financial policy class. 2008 to 2013 was of fiscal policy of profit and loss class and hysteretic fiscal policy class. In contrast, financial policy coordination is relatively advanced, and the fiscal policy is lagging behind. From composite index of the fiscal policy (f (x) )and composite index of 
financial policies x (g (y) ). From 2004 to 2013, f (x) and $\mathrm{g}(\mathrm{y})$ are in synchronous rising. After 2009 , the growth of $g(y)$ and the growth of $f(x)$ are gradually widening. In 2011, the difference attained to the maximum 0.124 . Thus the conclusions are as follows:

First, the current coordination development degree of fiscal policy and financial policy Heilongiiang Province of China is on the brink of Recession. Since 2008, the development of fiscal policies lags behind financial policy. Comprehensive condition of financial policy system is improved. Although the coordination degree of the two systems is improved, the fiscal policy is serious lag behind.

Second, coordination degree of fiscal and financial policy to promote the development of low-carbon economy in Heilongjiang Province of China is still much for improvement. We shall adopt the preferential taxation policy and strengthen financial support, and broaden financial services and capital investment, to ensure that the coordinated and sustainable development of the system.

4.3.2. Conclusion: First, from the perspective of systematic theory idea, constructs the index system evaluation of coordination development degree of fiscal policy and financial policy in Heilongjiang Province of China nearly a decade, to identify the coordinate state of system, which has important theoretical and practical significance for controlling and optimizing coordinate development of fiscal policy and financial policy in the future. Second, the evaluation results show that in recent 10 years, the coordinated development degree of fiscal policies and financial system in Heilongjiang Province of China is slowly rising. The development of fiscal policy is lagging behind financial policy. The lag effect of fiscal policy development in the future will be increasingly apparent. Constraint mechanism of system will be strengthened. Third, the analysis shows that coordinated development of the fiscal policy and financial policy system in Heilongjiang Province of China in the future still faces a series of major challenges. There is a certain difficult for the evolution of the coordinated development direction. It is a long way to go, to achieve synchronization goal of the coordinated development of the fiscal policy and financial policy.

\section{Countermeasures of Fiscal Policy and Financial Policy to Coordinate Promote Low Carbon Economy Development}

\subsection{The Implementation of Fiscal Policies Need Financial Policy to Cooperate}

5.1.1. Give Subsidies to Companies for Developing the Low-Carbon Economy: Fiscal policy is an important lever for the government to adjust economy. In order to achieve rapid economic growth, the government should encourage the enterprises to actively carry out independent research and innovation of low carbon technology, and adopts low carbon environmental protection equipment for production and operation. Government should give financial subsidies for enterprises developing low carbon economy. Enterprises should learn from foreign advanced experiences. The enterprises that purchase low carbon environmental protection equipments can take the method such as accelerated depreciation, to promote low-carbon economy to develop healthily and rapidly. Take data index of financial sector for reference to enterprises for fiscal subsidies, such as the business of bank credit record and green credit implement.

5.1.2. Improve Tax Policy Related to Low Carbon Cconomy: Tax policy is an important tool of government macroeconomic regulation and control, through the implementation of the tax policy to guide the development of low-carbon economy. Use tax policy to optimizing the allocation of resources; Use preferential tax policies to encourage enterprises to research and innovate low carbon technology [3].

Adjusting taxation scope of resource tax, green resource products of which the supply is relatively lack and should not be a large number of consumption will be 
included in the scope of taxation. The natural resources, social resources are included in the scope of taxation, expanding the resource tax base, levying reasonable resource tax, developing, using and protecting resources in order to achieve a low-carbon economy. It is recommended to build up a system of rewards and punishments system of resources tax. For energy-saving and environment-friendly enterprises, give some policy support, such as enterprises of low-emission behavior or adopting advanced technology equipment should be given corresponding preferential tax and compensation measures. While for high energy consumption, high emission and high pollution enterprises, not only reflected in the differences of tax but also set low energy consumption index in the enterprise applying for loans to limit high emission, high-polluting [4].

On the basis of the existing enterprise income tax system, improve income tax preferential policies for the enterprises that develop low-carbon economy. For low carbon enterprises researching and developing low carbon, environmental protection and new energy technology research can be taken reduction or exempted from corporate income tax. For severe pollution and low efficiency of enterprise can't take the same principle, should be encouraged to update the old machinery and equipment, improve the efficiency of resource utilization, and gradually transformed from "high carbon "to" low carbon". Especially at present most of the small profit-making enterprises' investment and development in the field of low carbon economy can not meet the national requirements when giving tax preference, but to see but to see their contribution in the development of low-carbon economy, should be appropriate to give tax preferential policies. Especially for small low-profit enterprises in addition to income tax preferential policies, but also to consider combining with the support of financial policies in this regard, so suggest establishing loan mechanism of deferred income tax for small profit-making enterprises.

\subsection{Financial Policy Implemented Needs the Support of the Fiscal Policies}

\subsubsection{Set up Policy-Related Financial System of Developing Low Carbon Economy:} For the development of low-carbon economy, in addition to develop the function of policy banks, such as China Development Bank, it also should set up special bank institutions for the low-carbon economy development, committed to all aspects of financial supports for low-carbon economy development. Make use of financial funds and financial bonds to raise funds to support the formation of low carbon economy development bank, and provide policy financial support to the development of low-carbon economy. Constantly improve the system of local financial institutions and play a supporting role to local financial institutions system in China in the development of low carbon economy [4]. Set carbon fund, learn from foreign carbon funds management concept and supervision mechanism, set up exclusive fund government agencies to respond to climate change, the fund managers from the government, enterprises and academic fields, ensure the reasonable use of fund [5]. This work requires national finance department to provide financial support for financial institutions, to ensure that banking institutions of low-carbon economy for effective developing.

\subsubsection{Improve Financial Institutions' Financial Innovation of Low-Carbon} Economy: According to the actual situation of China's low-carbon economy, the financial services sector should make a certain contribution, innovating financial products and enhancing the level of financial services. Suggest setting exclusive funds for low-carbon investment to guarantee the funds source of low-carbon project. To increase low carbon trading flow, low carbon credit trading platform should be established. The financial sector should launch financial products of low-carbon as soon as possible. For example: financial products, for the combination of trading number of carbon emissions, water resources and environmental 
protection, etc. Raise awareness of low-carbon economy through financial products. Adopt innovative financial intermediary service mode. Financial institutions should actively explore the low-carbon projects credit registration, custody, clearing and settlement services program, guide enterprises to develop new energy, energy conservation and emissions reduction work. Continue to develop new insurance products to meet our low-carbon economy development of our country, to further strengthen the forest carbon sinks insurance, credit insurance of carbon trading and green car insurance, etc, in promoting the low-carbon economy, reduce carbon emissions, reduce carbon emissions and climate change impact on the economic development of Negative Listing. According to the actual situation, the SFC should publish relevant policies, provide priority listing for enterprises that meet the requirements of low-carbon economy, and allow listed companies which meet the requirements of developing low-carbon economy and of which construction projects financing to invest in line with the development of low-carbon economy to issue new shares and priority allotment. On the contrary, should be given very strict restrictions to listed companies, in order to promote $\mathrm{f}$ listed companies to transform development mode, put more capital and technology towards a low-carbon economy [6].

5.2.3. Coordination between Fiscal Policies and Financial Policies: Fiscal policy represents positive direction of a country in the development of the fiscal policy in the future; there being guiding opinions and suggestions of the financial policy for the implementation. "The coordination of fiscal policy and financial policy is the perfect combination of an invisible hand and the visible hand." And good use of fiscal policy needs to give full play the role of financial policy, and to make effective use of the capital market direct financing and indirect financing.

No matter which fiscal policy or financial policy to boost the development of low-carbon economy is beyond all doubt. Fiscal and financial policy has always been an important means of government macro-control, and both of which are usually used in conjunction and the coordination is very important. To transform the government-led, market-assisted support model of traditional economic development into a new government-guided and diversified financial support model of low carbon economy development, we must change the role of government, by means of the market mechanism, and gradually play the role of market in the aspect of policy support. At the same time, for increasing financial input, government should give full play financial policy to support and guide the direction of low carbon economy development to promote coordinated development of fiscal and financial support.

\section{References}

[1] Q. Chuan, "Research on Fnancial Support for the Development of Low Carbon Economy in Shandong Province", Shandong: master degree dissertation in Shandong University, (2013).

[2] L. Chongbin, "Quantitative Evaluation and Classification System of Environment and Economy to be Coordinated Developed- Pearl River Delta Urban Agglomeration as an Example", Journal of tropical geography, vol. 2, (1999), pp. 172-174.

[3] B. Yang, "Research on the Fiscal Policies to Promote the Development of Low Carbon Economy", Beijing: Doctor Degree Theory of Chinese Academy of Social Sciences, (2014).

[4] L. Meng, "Concerning the Reform of Resource Tax in China under Low Carbon Economy", Journal of Xi 'an institute of finance and economics, vol. 2, (2011), pp. 127-128.

[5] Y. Zhonghai, "Build a Financial Policy System to Support Low Carbon Economy Development", Heilongjiang daily, June3rd, China, (2013).

[6] G. Te, "Research on Developing Low-carbon Economy", Jilin: master degree dissertation of Jilin University of Finance, (2013).

[7] W. Ke, "Based on the Perspective of Financial Support for Low-carbon Economy Development", Sichuan: the master degree dissertation of Southwestern University of Finance 
and Economics, (2013).

[8] O. Yangshu, "Research on Environment System Architecture based on Low-carbon Development in China", Hunan: doctor degree dissertation of Central South University, (2011).

[9] C. Liying, "Research on Fiscal Policy of Reducing Emissions in China", Liaoning, doctor degree dissertation of Liaoning University, (2011).

[10] X. Jijun, "Research on Public Policy of Developing Low-carbon Economy", Hubei: doctor degree dissertation of Huazhong University of Science and Technology, (2009). 
International Journal of $\mathrm{u}-$ and $\mathrm{e}-$ Service, Science and Technology Vol. 9, No. 12 (2016) 